\title{
An Overview of the Beneficial Effects of Hydrolysed Collagen as a Nutraceutical on Skin Properties: Scientific Background and Clinical Studies
}

\author{
Sara Sibilla ${ }^{1,{ }^{*}}$, Martin Godfrey ${ }^{1}$, Sarah Brewer ${ }^{2}$, Anil Budh-Raja ${ }^{3}$ and Licia Genovese ${ }^{1}$ \\ ${ }^{I}$ Minerva Research Labs Ltd, London, UK \\ ${ }^{2}$ Medilance (Guernsey) Ltd, UK \\ ${ }^{3}$ Dr. Anil Anti-Ageing and Parkfield Medical Centre, Birmingham, UK
}

\begin{abstract}
Skin, the main barrier to the external environment, is subject to deterioration caused by dermatological disorders, environmental conditions and the intrinsic ageing process. This damage to both structure and function may be accelerated by smoking, alcohol consumption and chronic sun exposure (extrinsic components). All these factors may lead to the formation of wrinkles, the appearance of brown spots and skin thickening. One effective strategy to managing the skin ageing process is adopting a healthy nutritional approach to life, maintaining a balanced diet and a good supply of food supplements. This can restore the homeostasis of macro and micronutrients and support the physiology of cells and tissues in the skin. Hydrolysed collagen, an increasingly popular nutraceutical, is composed of low molecular weight small peptides, which are easily digestible, absorbed and distributed in the human body. Numerous clinical trials have now been performed showing the efficacy and benefits of collagen peptides on skin properties, such as hydration, elasticity and reduction of wrinkles. As a result, hydrolysed collagen can be considered an important weapon in the everyday fight against skin ageing.
\end{abstract}

Keywords: Anti-ageing, hyaluronic acid, hydrolysed collagen, nutraceutical, nutritional supplement, skin, wrinkles.

\section{INTRODUCTION}

This review article examines the available data with regard to the use of hydrolysed collagen as a nutraceutical in skin ageing.

Below we bring together a thorough review of the basic physiology of collagen formation and its degradation during skin ageing and the beneficial effects of oral ingestion of hydrolysed collagen on skin properties such as hydration, elasticity and reduction of wrinkles.

\section{COLLAGEN}

Collagen is the main structural protein of the different connective tissues present in animals. It is mostly found in fibrous tissues, such as tendons and ligaments, and is also abundant in the cornea, cartilage, bones, blood vessels, the gut, and intervertebral discs (Table 1). Collagen is the major insoluble fibrous protein found in the extracellular matrix of the skin, together with elastin and hyaluronic acid. The collagen family consists of 28 different proteins [1,2], which account for $25 \%$ - $35 \%$ of the total protein mass in mammals and play a pivotal role in the structure of several tissues, such as skin and bones, providing rigidity and integrity

*Address correspondence to the author at the 1-6 Yarmouth Place, London, W1J 7BU, United Kingdom; Tel: +44(0)7805064508;

E-mail: ssibilla@minervalabs.com
$[3,4]$. The extracellular matrix (ECM) of connective tissues is formed by diverse protein families involved in the structural integrity and several physiological functions. Composition and structure of the ECM vary considerably in the different types of connective tissues and result in unique functional and biological characteristics [5].

Based on their structure and three-dimensional organization, the collagen family of proteins can be grouped into fibril-forming collagens, fibril-associated collagens (FACIT), network-forming collagens, anchoring fibrils, transmembrane collagens (MACIT), basement membrane collagens and others with unique functions $[2,5]$.

In the human body $80-90 \%$ of the total collagen consists of the fibril-forming collagens. Type II and XI collagen fibrils are involved in the formation of the fibrillar matrix in the articular cartilage [5-7].

Type IV collagen, in contrast, forms a two-dimensional reticulum and this more flexible triple helix is restricted to basement membranes [5, 8].

Multiple triple helices form a collagen fibril and multiple fibrils pack together to form a collagen fibre (Fig. (1)). Generally collagen fibrils are made of different collagen types: collagen I and III in the skin; collagen II and III in cartilage [4]. The diversity of the collagen family (collagen I, II, III) is mainly determined by the existence of several $\alpha$ chains with different number of amino acids. Type I collagen 
Table 1. The five most common types of collagen.

\begin{tabular}{|l|l|}
\hline \multicolumn{1}{|c|}{ Type } & \\
\hline \hline Type I & dermis, tendon, ligaments and bone \\
\hline Type II & cartilage, vitreous body, nucleus pulposus \\
\hline Type III & skin, vessel wall, reticular fibres of most tissues (lungs, liver, spleen ...) \\
\hline Type IV & forms the basal lamina, the epithelium-secreted layer of the basement membranes \\
\hline Type V & lung, cornea, hair, fetal membranes and bones \\
\hline
\end{tabular}

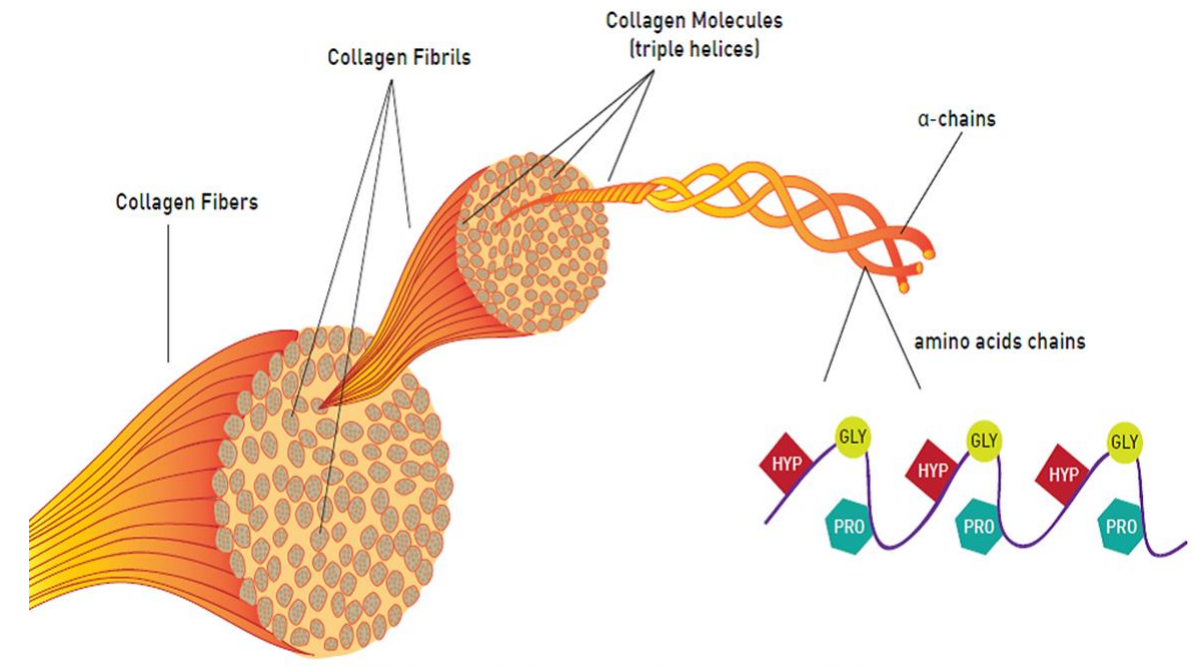

All rights reserved. @ 2011 Copyright MINERVA Research Labs Ltd

Fig. (1). Structure of the collagen fibres.

is the most abundant in the human body: it forms more than $90 \%$ of bone organic mass and it is the major collagen of tendons, ligaments, cornea and many interstitial connective tissues. It is also the main component of human skin $(80 \%)$ with collagen type III making up the remainder of skin collagen $(15 \%)[5,9]$.

The unique physical properties of collagen fibres confer structural integrity to the skin forming a dense network throughout the dermis. The main function of this network is to provide structural support to the epidermis. In addition, collagen and elastin together form the extracellular matrix, which gives the skin its structure, elasticity and firmness [10] (Fig. (3)).

Collagen is mainly produced by fibroblasts in the connective tissues [2] but also numerous epithelial cells make certain types of collagens. The different collagens and the structures they form have the purpose to help tissues resist stretching. Fibroblasts are connective tissue cells in the dermis which are responsible for producing and organising the collagen matrix. Fibroblasts are sensitive to physical and chemical stimuli, which can induce both fibroblast activation and proliferation. Chemical stimuli are based on a "keylock" mechanism where small ligands bind receptors located on the fibroblast extracellular membrane inducing their activation [11]. Physical stimuli are directly related to the interactions between collagen and fibroblasts. The activation of fibroblasts results in an increase in the production of collagen (Fig. (2)).

\section{SKIN AGEING}

Skin is subject to deterioration caused by dermatological disorders, environmental conditions (wind, air conditioning, heating) and the intrinsic ageing process, which may be accelerated by exposure to sun (photo-ageing $[12,13]$ ) or by other lifestyle issues (extrinsic ageing: smoking, alcohol, stress, lack of sleep and chronic sun exposure [14, 15]). All these factors may cause the formation of wrinkles, the appearance of brown spots and the thickening of the skin $[12,13]$. Interestingly, alteration in diet can change the way skin functions as evidenced by the effects of dietary deprivation on skin health. For example essential fatty acid deficiency [16] or accumulation of abnormal fatty acids [17] results in so-called skin scaling and poor barrier function. Moreover, a recent publication shows that in a placebo controlled double blind study the addition, in the diet, of the omega-3 oils from flaxseed and omega-6-rich oils from the borage plant leads to a decrease in skin roughness and scaling, $(\mathrm{P}<0.05)$ [18].

Autoimmune diseases, ageing and stress can change the quantity and integrity of collagen in the skin as they impair collagen quality and consequently affect the overall skin function. Studies have also shown that collagen synthesis varies at the different stages of life. Moreover, the relative 
proportion of the collagen types changes in skin with age. Young skin is made by $80 \%$ type I collagen and about $15 \%$ collagen type III. With age, the ability to replenish collagen naturally decreases by about $1.5 \%$ per year. Collagen fibres, in aged skin, become thicker and much shorter, resulting in a loss of type I collagen, which alters the ratio of collagen types [19]. The density of collagen and elastin in the dermis declines, hence the structure and elasticity of the skin degrades, causing it to become thinner and more rigid. The ageing process results also in the loss of hyaluronic acid. This reduces the moisture, suppleness and elasticity of the skin. The diminished elasticity of the skin reduces its ability to retain its shape and it does not conform as closely to the contours of the face. The skin appears looser and sags. Lines and furrows emerge to enable movement. Gravity then pulls on the skin, all leading to sagging eyelids, bags under the eyes and jowls.

Skin ageing is a complex biological process which affects several constituents of the skin and hence its appearance. The two primary processes of skin ageing, intrinsic and extrinsic, are controlled, respectively, by genetic variations and by extrinsic components (Fig. (4)) [20]. Skin ageing alterations are due to structural changes in the skin cells and in the texture of the dermal tissue, because of the action of free radicals (reactive oxygen species, ROS) produced mostly by UV radiation and to a certain extent by cellular metabolism. ROS induce a molecular destruction and consequently the loss of biological functions [21].

Another important phenomenon that takes place, especially in tissues very rich in proteins, is the production of AGEs (Advanced Glycation End products). These molecules

\section{MECHANISM OF COLLAGEN FORMATION}

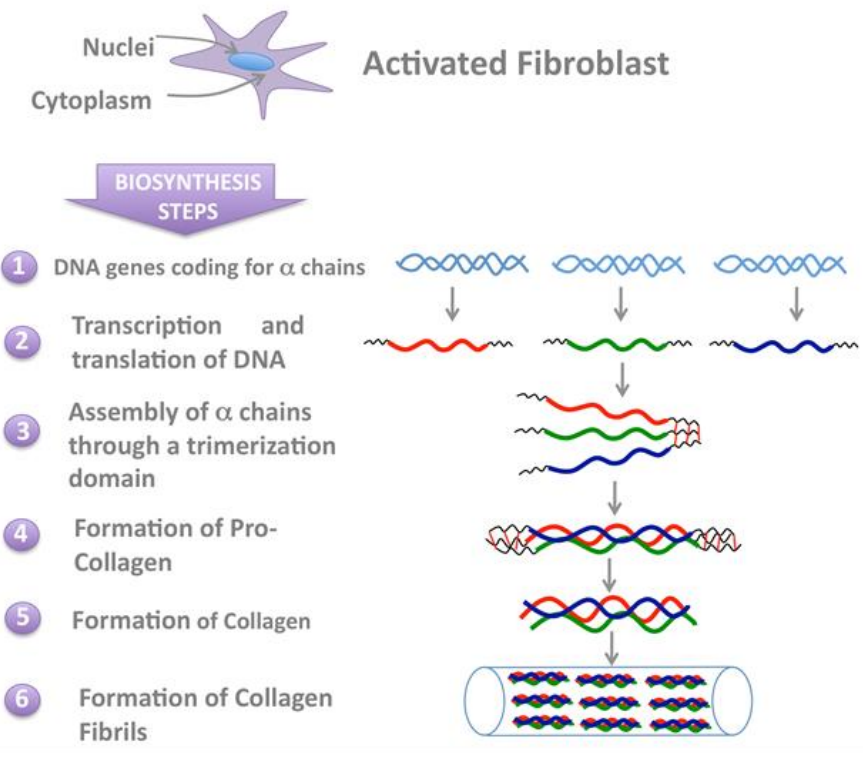

All rights reserved. 02011 Copyright MINERVA Research Labs Ltd

Fig. (2). Collagen synthesis.

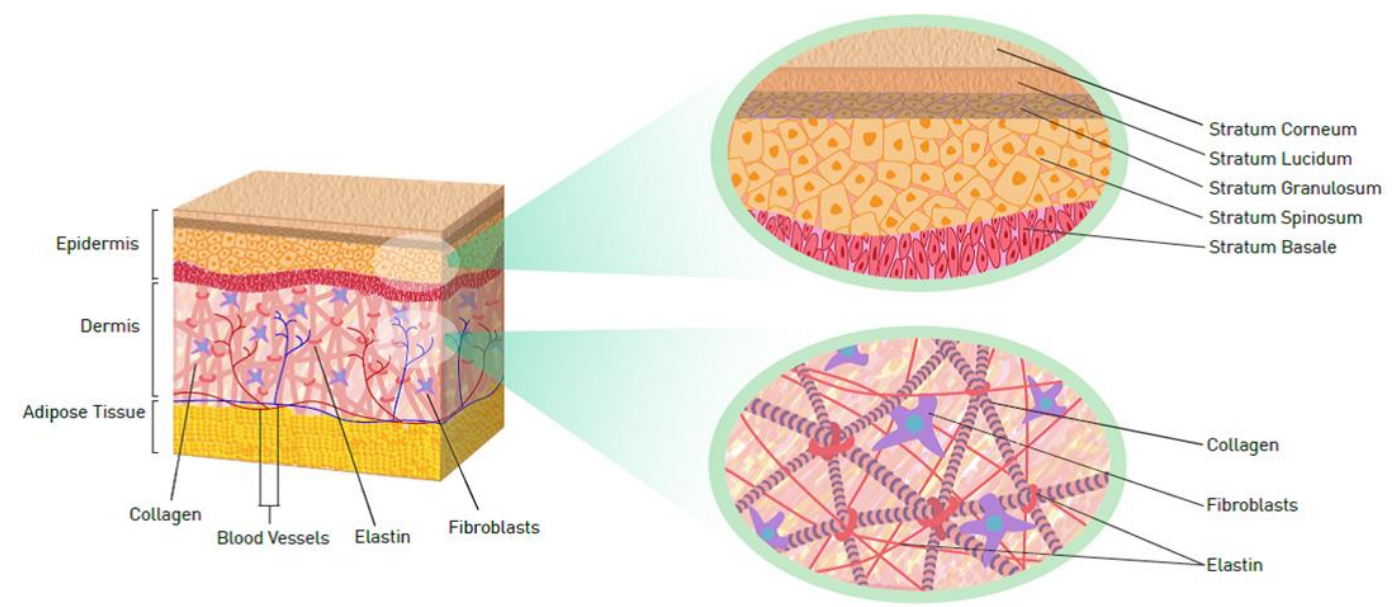

All rights reserved. @ 2011 Copyright MINERVA Research Labs Ltd

Fig. (3). Diagram showing the structure of healthy skin, in which the different layers are visible: epidermis, dermis and adipose tissue. Collagen fibres, elastin and fibroblasts are also represented in the diagram. 
form because of a chemical reaction between glucose and the free amino groups in proteins and they remain in the tissue where they form for long periods because they cannot be degraded normally by enzymes [22]. Moreover, compared to young adult fibroblasts, aged fibroblasts synthesize lower levels of collagen, both in vitro and in vivo [23]. An ageing dermis is characterized by changes in the production and formation of collagen and elastin fibres. In fact, photo-aged dermis contains disorganized collagen fibres and accumulated abnormal elastin [24, 25]. Also smoking leads to changes in the components of the dermis. Therefore smoking can cause premature ageing of the skin [22, 26]. In addition, several studies have correlated the release of stress hormones, such as glucocorticoids (GC), to changes in the synthesis and degradation of collagen in the skin. An important indicator of the deleterious effects of chronic stress is the dysregulation of the circadian cortisol/ corticosterone rhythm $[27,28]$. In response to stress, corticotrophinreleasing factor initiates a cascade of events that end up in the release of GC from the adrenal cortex. GC are able to affect the quality of skin through modulation of the immune system [29]. In the short term, GC release may play a key role in the survival of an organism but its excess can lead to negative effects on almost all tissues [30] and accelerate the ageing process [31].

One answer to the ageing process affecting skin condition and function because of lifestyle, dieting or time passing by, is having a correct nutritional approach, maintaining a balanced diet and a good supply of food supplements to restore the homeostasis of macro- and micronutrients to support the physiology of cells and tissues in the human body.

\section{HYDROLYSED COLLAGEN}

Hydrolysed collagen consists of small peptides with low molecular weight $(0.3-8 \mathrm{kDa})$, produced from native collagen which is found in bones, skin and connective tissue

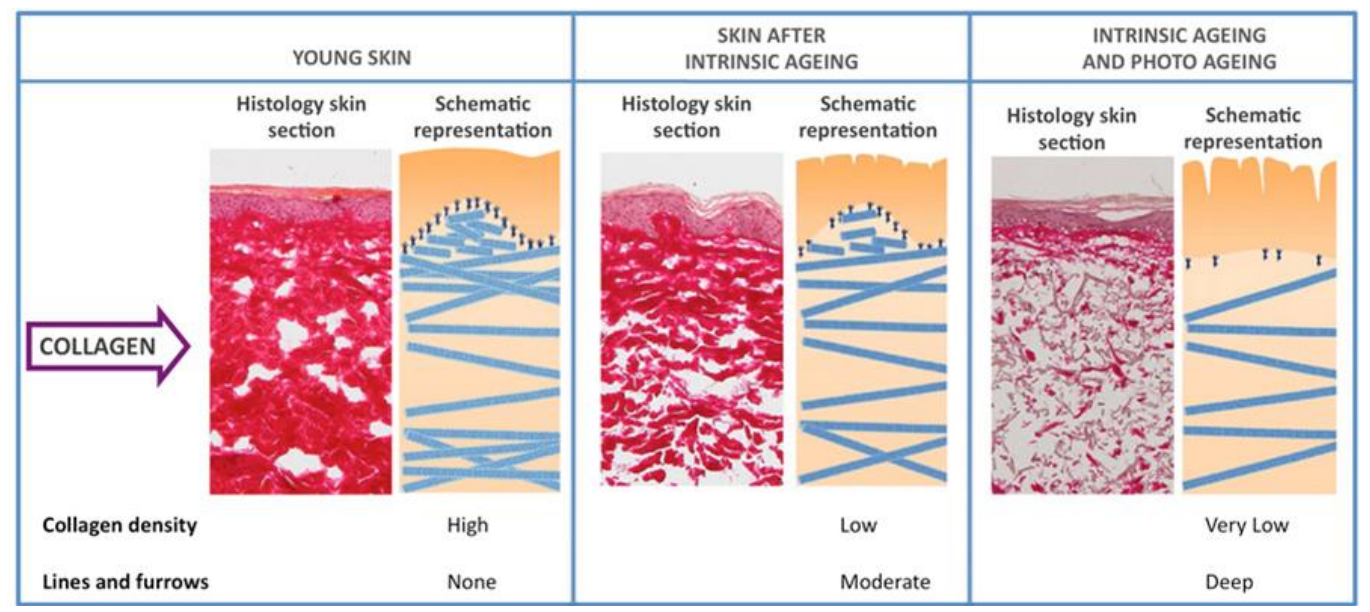

Graph modified from: E. C. Naylor, Maturitas, 2011, 69, 249-256.

Fig. (4). Collagen decreases after intrinsic and extrinsic ageing [14].

INDUSTRIAL PRODUCTION OF HYDROLYSED COLLAGEN

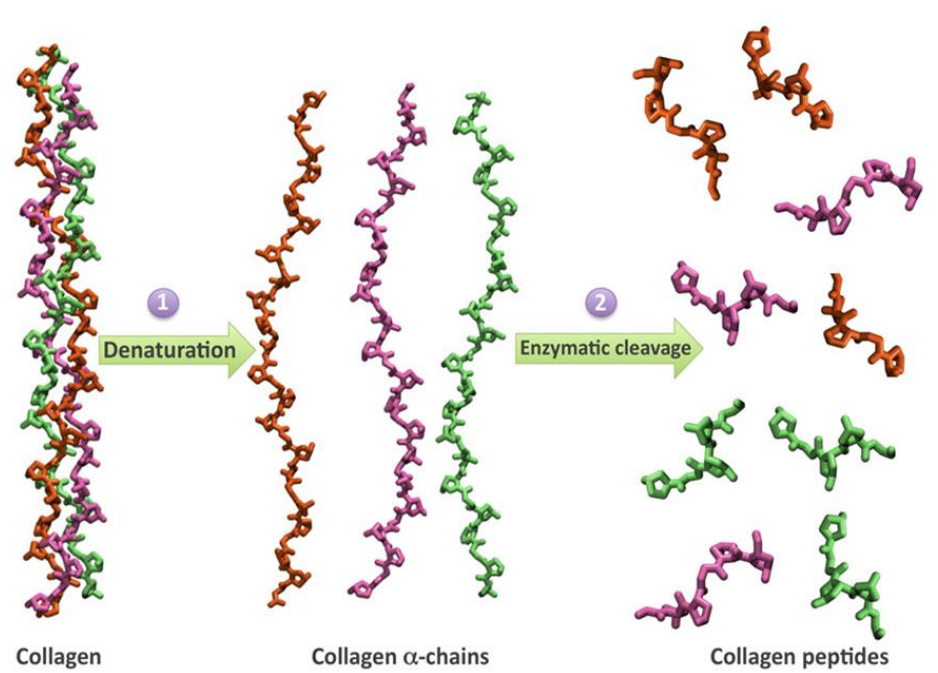

All rights reserved. @ 2011 Copyright MINERVA Research Labs Ltd

Fig. (5). Industrial production of hydrolysed collagen. 
of animals (i.e. cattle, pigs and fish). Due to its low molecular weight, hydrolysed collagen is easily digestible, absorbed and distributed in the human body.

The quality of the final hydrolysed collagen is dependent on its average molecular size, which can vary based on the methodology used to extract it. Generally, collagen molecules are denatured and partially hydrolysed to form gelatin (100 $\mathrm{kDa}$ ). Gelatin can then be decomposed into small peptides using specific enzymes with cleavage activity (proteinase) (Fig. (5)). The molecular weight distribution of collagen peptides usually span in the range $0.3-8 \mathrm{kDa}$. Due to the low molecular weight, there are several advantages of using hydrolysed collagen with respect to native collagen:

- hydrolysed collagen is highly digestible;

- hydrolysed collagen is easily absorbed and distributed in the human body.
When administered orally, hydrolysed collagen reaches the small intestine where it is absorbed into the blood stream, both in the form of small collagen peptides and free amino acids. Through the network of blood vessels, these collagen peptides and free amino acids are then distributed in the human body, in particular to the dermis, where it has been proven they can remain up to 14 days [32]. In the dermis, hydrolysed collagen has a dual action mechanism: 1) free amino acids provide building blocks for the formation of collagen and elastin fibres; 2) collagen oligopetides act as ligands, binding to receptors present on the fibroblasts' membrane and stimulate the production of new collagen, elastin and hyaluronic acid.

Hydrolysed collagen is enriched in specific amino acids: glycine, proline and hydroxyproline. Each amino acid has a particular function. The amino acid profile is shown in (Fig. (6)).

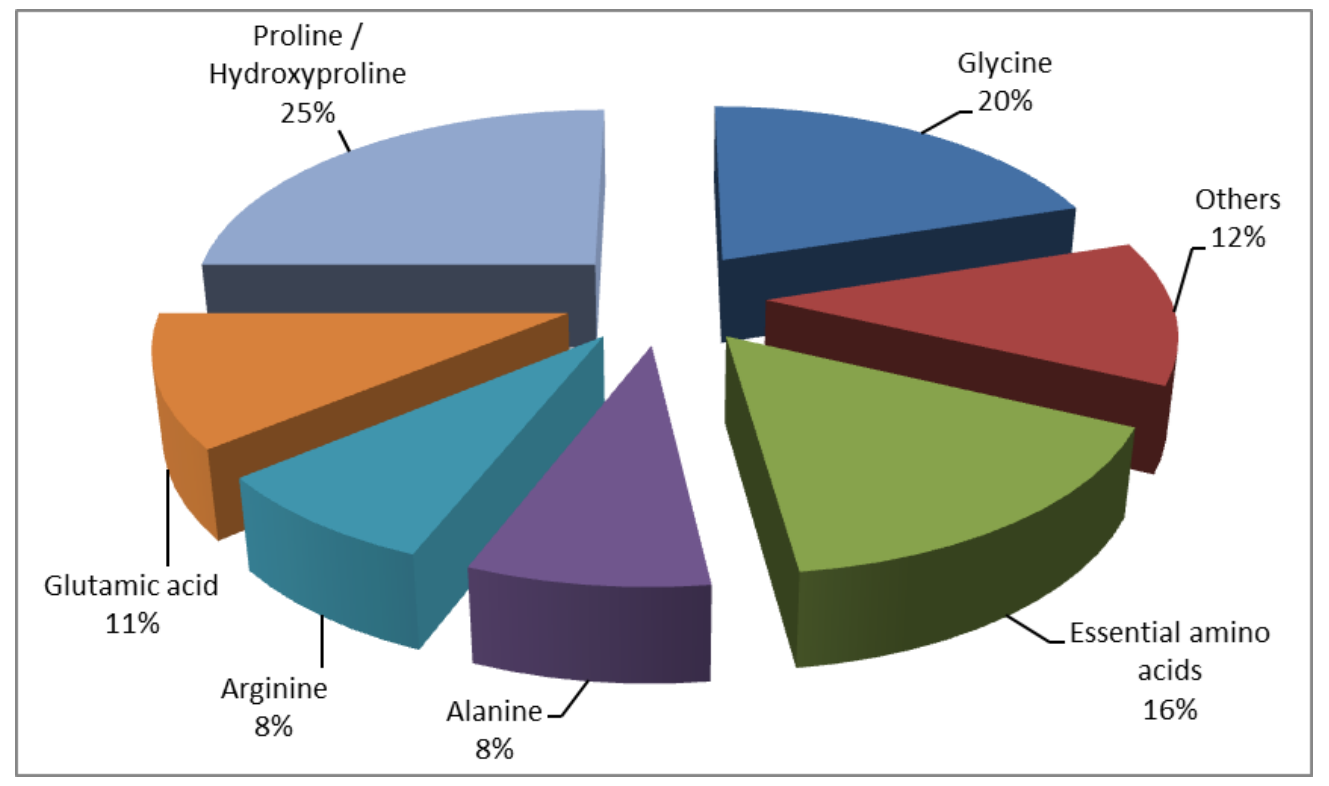

Fig. (6). Study conducted by Rousselot SAS, a French manufacturer of hydrolysed collagen (unpublished results).
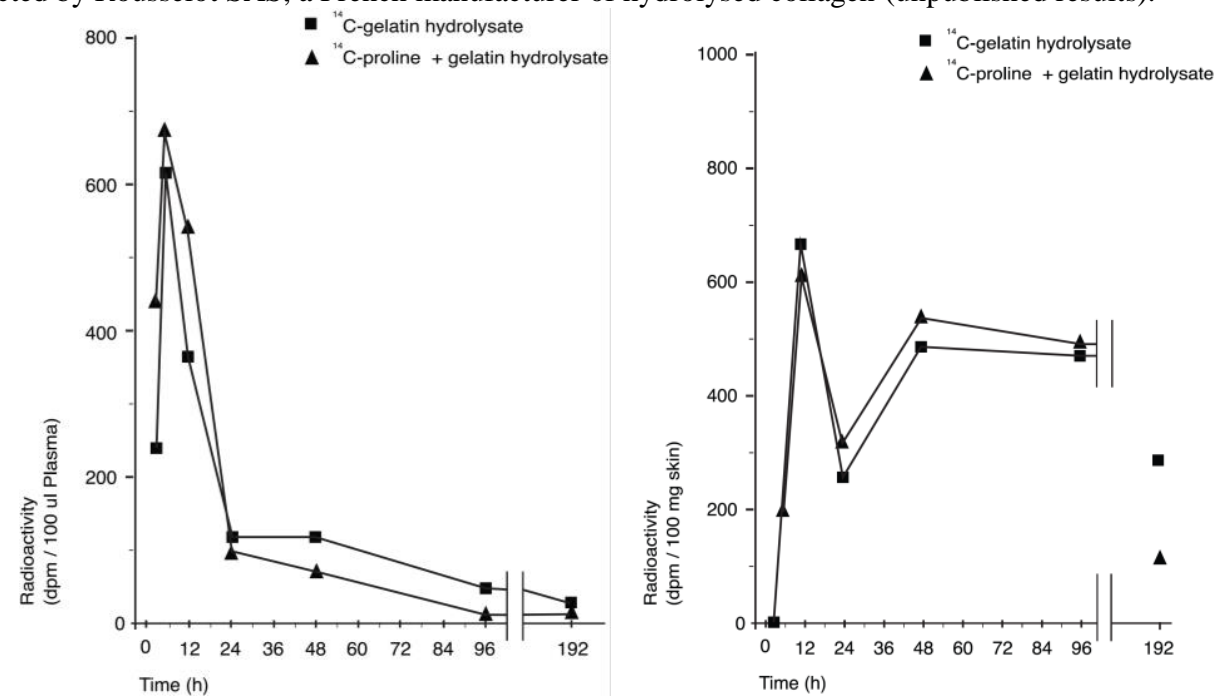

Fig. (7). Time course of radioactivity in plasma (left graph) and skin (right graph) of mice subsequent to the absorption of orally administered ${ }^{14} \mathrm{C}$-labeled gelatin hydrolysate or of ${ }^{14} \mathrm{C}$-labeled proline in the control group (Graph taken from Ref. [34]). 


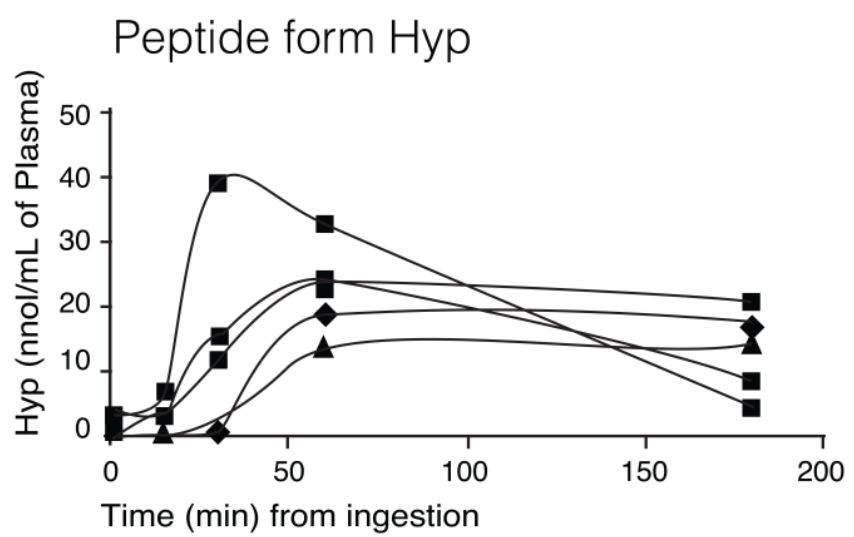

Fig. (8). Serum levels of hydroxyproline in peptide forms after oral ingestion of gelatin hydrolysate. (Graph taken from Ref. [35]).

Collagen and gelatin have long been used as a food source and/or supplement. Interestingly, collagen peptides have been shown to have an impact on weight loss and to be effective at maintaining weight, with no adverse effects (Rousselot - Collagen peptides and nutrition). The Food and Drug Administration (FDA) has classified gelatin, from which collagen peptides are prepared, as a safe substance. In addition, based on international research results, both the World Health Organization (WHO) and the European
Commission for Health and Consumer Protection have confirmed that hydrolysed collagen is safe. Rarely minor side effects, such as nausea, flatulence or dyspepsia, may occur in some people by ingesting collagen peptides. In conclusion, the safety of collagen peptide and gelatin is widely recognized. (http://www.accessdata.fda.gov/scripts/f $\mathrm{cn} / \mathrm{fcnDetailNavigation} . \mathrm{cfm} ? \mathrm{rpt}=\mathrm{scogslisting} \& \mathrm{id}=141 \mathrm{http}: / /$ www.gelatine.org/about-hydrolysed-collagen/safety.html http://www.efsa.europa.eu/en/efsajournal/doc/174.pdf).

\section{DIGESTION AND ABSORBTION}

In order to be active in the deeper layer of the skin, hydrolysed collagen must cross the intestinal barrier and reach the blood stream. It is worth noting that the rate of transport across the intestinal barrier could limit the efficacy of these compounds in the skin. Therefore, before speculating about their mechanism of action, it is important to demonstrate in what form and quantity collagen peptides can be absorbed.

According to Richelle et al. [33], bioavailability is defined as the relative amount of a dietary bioactive compound that crosses the intestinal barrier, reaches the blood circulation and is available for metabolic process or storage in the body (in this context, the skin).

Table 2. Scientific studies on the bioavailability of hydrolysed collagen.

\begin{tabular}{|c|c|c|c|}
\hline Source & Hydrolyzed collagen concentration & Method & Results \\
\hline $\begin{array}{l}\text { Oesser et al. [34] } \\
\text { Fig. (7) }\end{array}$ & $\begin{array}{l}10 \mathrm{mg} \text { of }{ }^{14} \mathrm{C} \text {-labeled gelatin } \\
\text { hydrolysate/g body weight }\end{array}$ & $\begin{array}{l}\text { 1) Testing on male mice: the test } \\
\text { group received } 10 \mathrm{mg} \text { of }{ }^{14} \mathrm{C} \text { - } \\
\text { labeled gelatin hydrolysate/g body } \\
\text { weight, while the control group } \\
{ }^{14} \mathrm{C} \text {-labeled proline, together with } \\
\text { unlabeled gelatin hydrolysate (10 } \\
\text { mg/g body weight). } \\
\text { 2) SDS-electrophoresis and HPLC } \\
\text { to quantify the molecular weight } \\
\text { distribution of the absorbed } \\
\text { hydrolysed collagen. }\end{array}$ & $\begin{array}{l}\text { 1) } 90 \% \text { of orally administered hydrolysed collagen } \\
\text { was absorbed within the first } 12 \text { hours from the } \\
\text { intake. Radioactivity in skin reached its peak values } \\
12 \text { hours after the administration of }{ }^{14} \mathrm{C} \text {-labeled } \\
\text { hydrolysed collagen and remained relatively high } \\
\text { up to } 96 \text { hours in contrast to plasma. } \\
\text { 2) Hydrolysed collagen peptides within a range } \\
\text { from } 1 \text { to } 10 \mathrm{kDa} \text { were found on the serosal side of } \\
\text { the intestine, indicating that collagen hydrolysate } \\
\text { may be absorbed to some extent also in the high } \\
\text { molecular form. }\end{array}$ \\
\hline $\begin{array}{l}\text { Iwai et al. [35] } \\
\text { Fig. (8) }\end{array}$ & 9.4-23 g of hydrolysed collagen. & $\begin{array}{l}\text { Human volunteers ingested } \\
\text { hydrolysed collagen from porcine } \\
\text { skin, chicken feet, and cartilage } \\
\text { after } 12 \text { hours of fasting. }\end{array}$ & $\begin{array}{l}\text { 1) Hydroxyproline-containing peptides increased in } \\
\text { amount after collagen intake and reached a peak } \\
\text { level after } 2 \text { hours till they decreased later on to half } \\
\text { of the maximum level after } 4 \text { hours from the oral } \\
\text { ingestion. } \\
\text { 2) Identification of high levels of a small peptide } \\
\text { proline-hydroxyproline (Pro-Hyp) found in the } \\
\text { blood after hydrolysed collagen intake. }\end{array}$ \\
\hline Ohara et al. [36] & $\begin{array}{l}\text { Food-derived gelatin from three } \\
\text { sources of type I collagen. }\end{array}$ & $\begin{array}{l}\text { Five healthy male volunteers } \\
\text { ingested, after } 12 \text { hours of fasting, } \\
\text { type I gelatin hydrolysates from } \\
\text { fish scale, fish skin, or porcine } \\
\text { skin. }\end{array}$ & $\begin{array}{l}\text { The aim of the study was to compare the quantity } \\
\text { and structures of food-derived gelatin hydrolysates } \\
\text { in human blood from three sources of type I } \\
\text { collagen. Over a 24-hours period, amounts of Hyp } \\
\text { containing peptides comprised around } 30 \% \text { of all } \\
\text { detected Hyp. The total area under the concentration } \\
\text { time curve of the fish scale group was significantly } \\
\text { higher than that of the porcine skin group. }\end{array}$ \\
\hline
\end{tabular}


The first step of digestion consists in the degradation of hydrolysed collagen to form dipeptides and tripeptides or free amino acids. Several proteases (e.g. pancreatic proteases; small intestinal brush-border proteases; peptidase) are involved in the degradation process.

Several scientific studies done in animals and humans have described the bioavailability of hydrolysed collagen after oral administration and are summarized in Table $\mathbf{2}$.

It is commonly assumed that prior to absorption, peptides are hydrolysed in the gastrointestinal tract, so predominantly the free amino acids enter the circulation [37, 38]. However, there is considerable evidence that peptides can also be absorbed. For example Hyp is absorbed in both amino acid (free form) and peptide form. Pro-Hyp is the major peptide found in human plasma after oral ingestion of any hydrolysed collagen.

The mechanism of absorption across the intestine membrane has been extensively studied. Epithelial cells are the principal site of absorption of several nutrients. There are three possible mechanisms for the transport of oligopeptides through the intestine: (i) PEPT1 mediated transcellular transport for di- and tripeptides [39], (ii) a transcytotic route known to be used for the transport of macromolecules (such as proteins) [40], and (iii) intracellular passive transport for the absorption of peptides [41]. However, the role of these pathways in intestinal oligopeptide absorption is not completely understood.

The trans-cellular transport of these peptides mediated across intestinal epithelial cells is a two-step mechanism, which involves the transport across two different membranes: i) peptide take up by the epithelial cell from the lumen across the brush-border membrane; ii) absorption into the blood stream across the basolateral membrane [42]. The first step is mediated by $\mathrm{H}^{+}$-coupled peptide transporters (PEPT1 and PEPT2). In particular the transporter PEPT1 operates an enantioselective transport of neutral and mono or polyvalently charged peptides [43]. It has been shown that
Liver

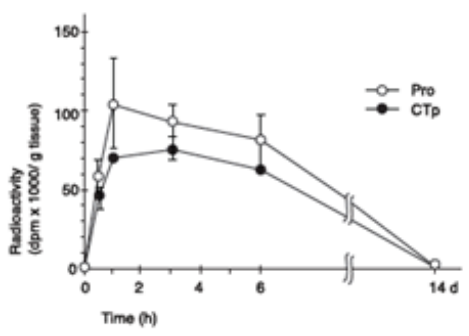

Cartilage

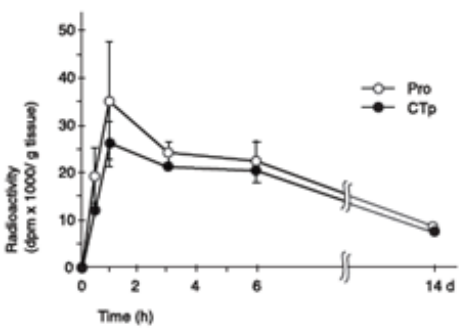

Brain

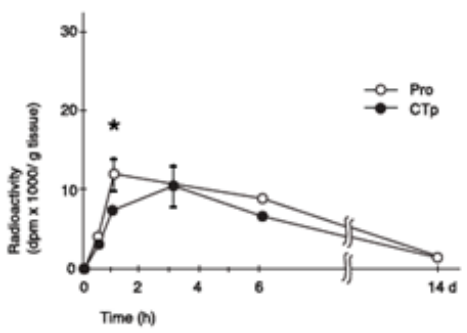

Kidney

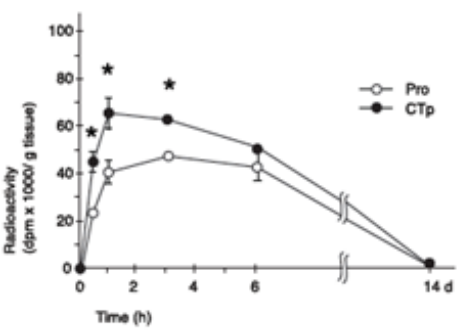

Femur

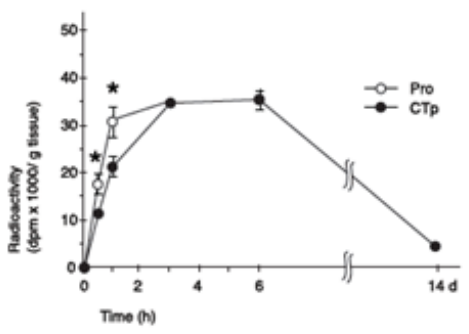

Muscle

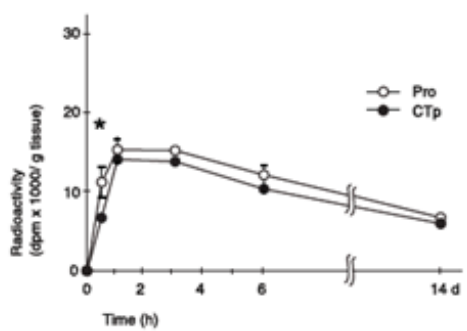

Spleen

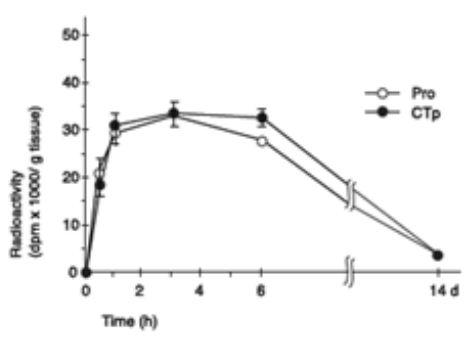

Tibia

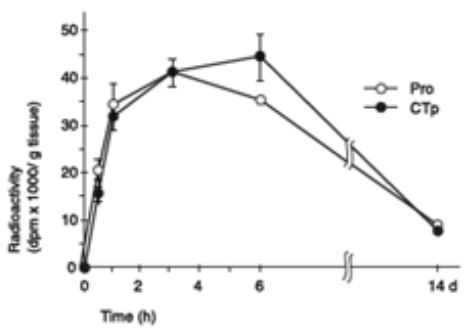

Skin

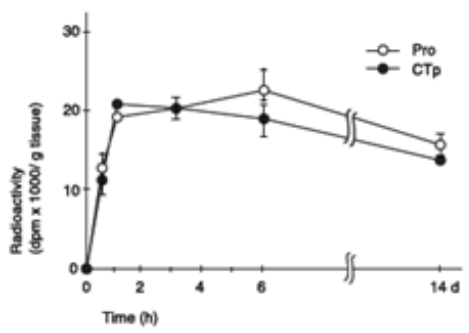

Fig. (9). Tissue distributions of radioactivity in rats administered with collagen peptides. (Graph taken from Ref. [32]). 
collagen derived peptides (proline-hydroxyproline and glycine-proline-hydroxiproline) are absorbed through PEPT1 transporter [43].

\section{DISTRIBUTION}

Distribution is usually defined as the process by which a compound reaches the target tissue through the blood circulation. Factors that can affect the rate of distribution are the blood flow or chemical feature of a given compound such as molecular size or polarity.

Watanabe-Kamiyama et al. [32] studied the distribution of collagen peptides to the skin and other tissue by means of an in vivo experiment, where proline or collagen peptides ${ }^{14} \mathrm{C}$-labeled were administered to Wistar rats. Radioactivity was measured in the different tissues after ingestion of the collagen peptides and/or proline during 0 to 6 hours and until 14 days (Fig. (9)). The results were very promising in terms of residence in the skin and showed that the radioactivity remains in this tissue at high levels up to 14 days. This indicates the ability of collagen peptides to reach the dermis in the skin where their main benefit is observed.

\section{ACTION IN THE DERMIS}

As previously described, several experiments have shown that collagen peptides can be efficiently absorbed and
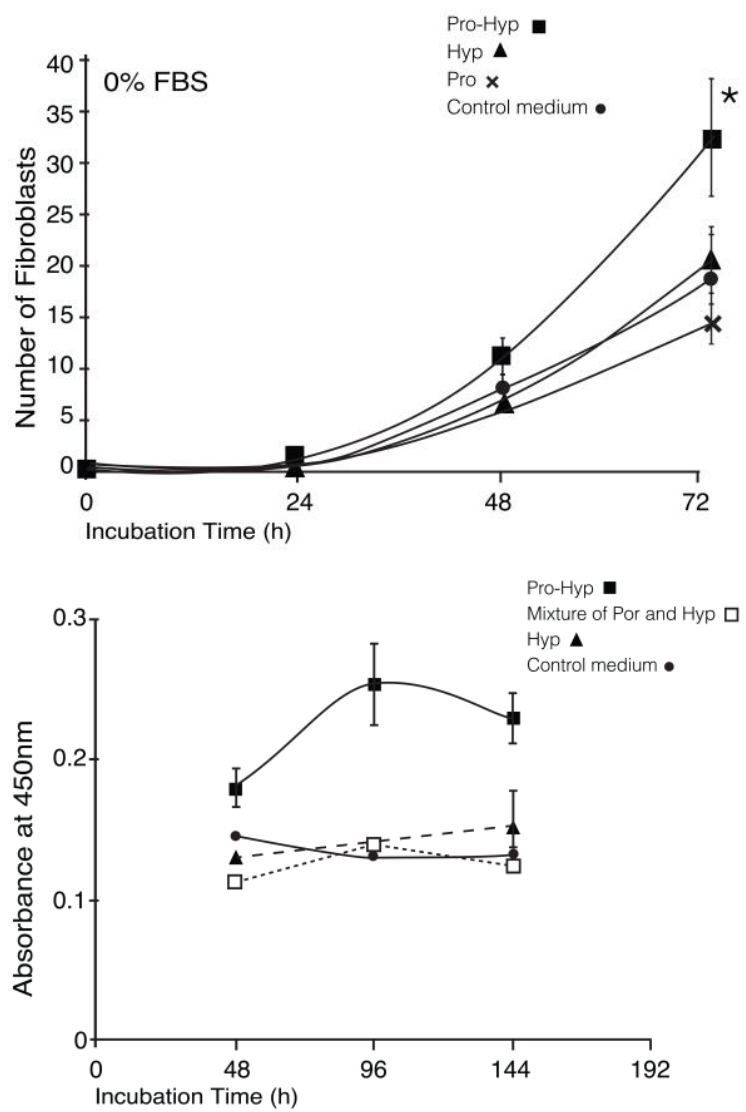

Fig. (10). Fibroblast migration (left graph) and proliferation (right graph) induced by Pro-Hyp ( $\boldsymbol{\square})$, Hyp $(\boldsymbol{\Delta})$, Pro $(\bullet)$ and the control medium $(\times)$. (Graph taken from ref. [45]). distributed to the deepest skin layers. However, this still does not represent a proof of their efficacy.

The final step is to understand whether collagen peptides can be active in the skin and what is the mechanism of action. Several in vitro and in vivo studies have proven the efficacy of these peptides, evidencing their ability to target fibroblasts. In the following Tables (Table $\mathbf{3}$ and Table 4) are described some key studies that illustrate the ability of collagen peptides to: 1) stimulate the proliferation and motility of fibroblasts; 2) induce an increase in collagen fibres' density and diameter in the dermis; 3) increase hyaluronic acid production; 4) activate protection against UVA radiation.

\section{CLINICAL TRIALS HAVE PROVEN THE EFFICACY OF HYDROLYSED COLLAGEN}

Skin ageing is caused by several factors: ionizing Cutaneous hydration
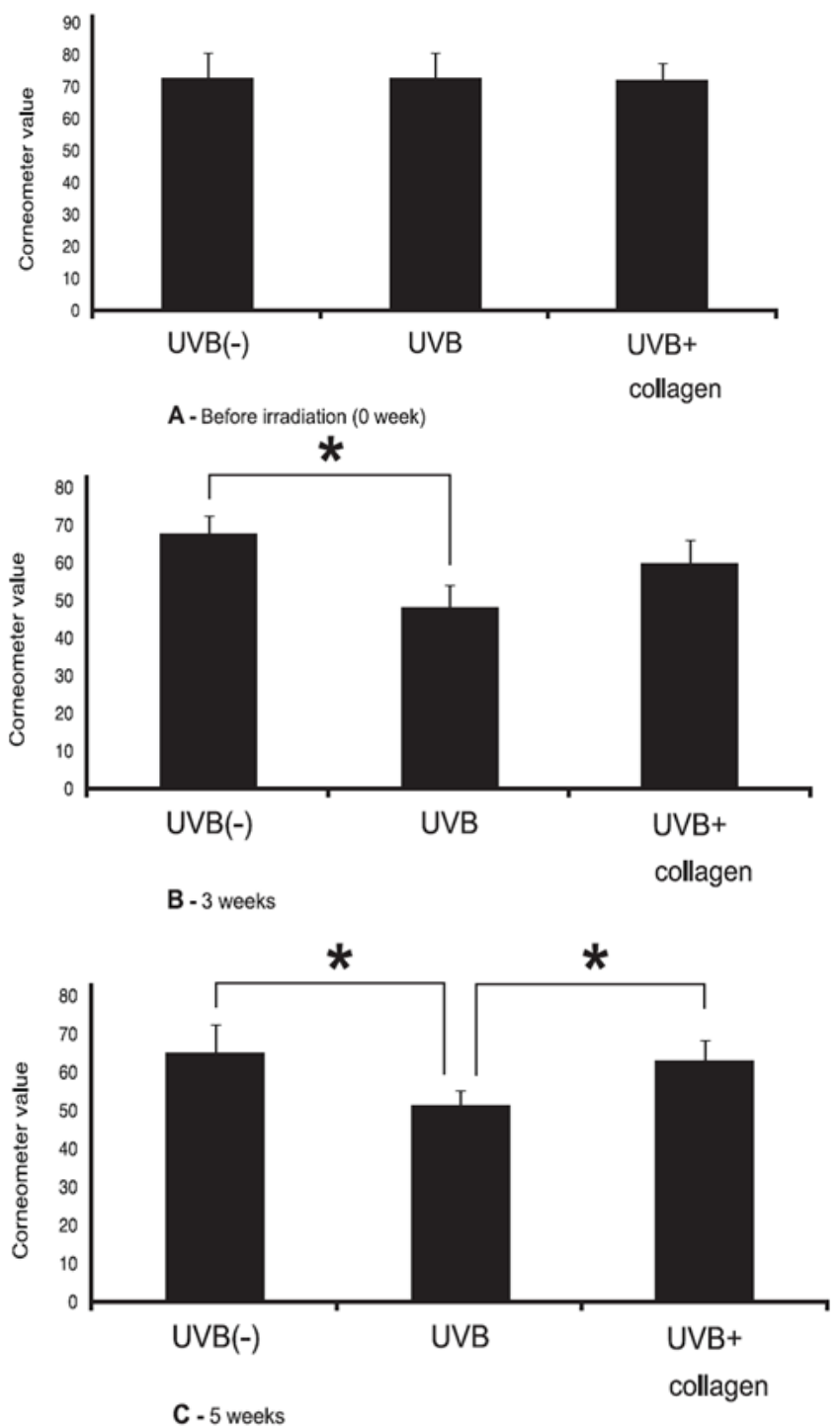

Fig. (11). Effects of UV-B irradiation and hydrolysed collagen on stratum corneum hydration from Ref [49]. 
radiation, physical and psychological stress, alcohol intake, poor nutrition, overeating, environmental pollution, and exposure to UV radiation [52]. In order to better study the different benefits of hydrolysed collagen on skin, controlled clinical trials are needed in addition to the previous preclinical and bioavailability assays. Up to date several clinical trials have been performed proving the efficacy of collagen peptides.

Two studies conducted by Rousselot SAS of France have investigated the effect of hydrolysed collagen on skin hydration and reduction of deep wrinkles. In the first study a double-blind, randomised, placebo-controlled clinical trial was carried out in Japan on 33 women aged 40-59 years with normal to dry skin. The results showed a $28 \%$ increase in skin hydration by taking $10 \mathrm{~g}$ of hydrolysed collagen (Fig. (12)).

In the second study a double-blind, randomised, placebocontrolled clinical trial was carried out in France on 47 women aged 35-55 years with normal to dry skin. The positive outcome showed a $30 \%$ decrease in the formation of deep wrinkles, after supplementation of $10 \mathrm{~g}$ of hydrolysed collagen (Fig. (13)).

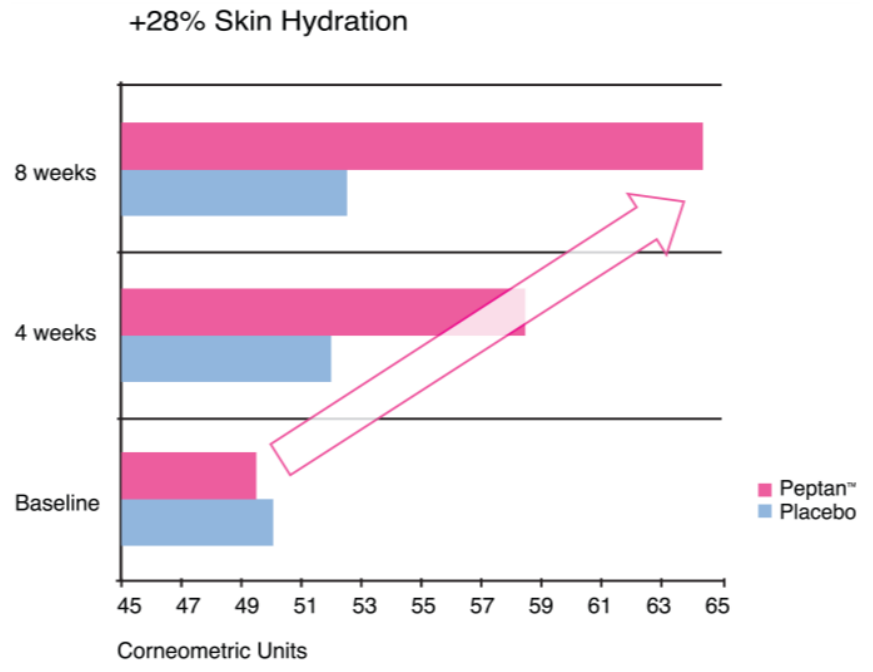

Fig. (12). Clinical trials on skin hydration. (Unpublished results by a study from Rousselot).

Other up to date clinical trials are shown in Table 6.

Table 3. In vitro scientific studies on the efficacy of collagen peptides.

\begin{tabular}{|c|c|c|}
\hline Source & Aim of the study & Results and main conclusions \\
\hline Postlethwaite et al. [44] & $\begin{array}{l}\text { To analyse the chemotactic response of human } \\
\text { dermal fibroblasts to type I, II, and III human } \\
\text { collagens and collagen derived peptides by an } \\
\text { in vitro assay. }\end{array}$ & $\begin{array}{l}\text { All three native human collagens and constituent } \alpha \text {-chains serve as in } \\
\text { vitro chemo-attractants for fibroblasts. } \\
\text { In addition, also di- and tri-peptides containing hydroxyproline resulted } \\
\text { chemotactic for fibroblasts. The authors suggested that both collagen } \\
\text { and collagen derived peptides might function as chemotactic stimuli for } \\
\text { fibroblasts in vivo and attract these cells for the repair of damaged } \\
\text { tissues. }\end{array}$ \\
\hline $\begin{array}{c}\text { Shigemura et al. } \\
\text { Fig. (10) }\end{array}$ & $\begin{array}{l}\text { To investigate the influence of collagen } \\
\text { peptides on migration and growth of mouse } \\
\text { skin fibroblasts. }\end{array}$ & $\begin{array}{l}\text { The authors report that the number of cells migrating from the } \\
\text { explanted skin increased significantly after treatment with Proline- } \\
\text { hydroxyproline peptide. However they also found contrasting results } \\
\text { and finally concluded that Pro-Hyp has a minor effect on fibroblasts' } \\
\text { motility. On the other hand they showed that Pro-Hyp increases } \\
\text { significantly fibroblasts growth. }\end{array}$ \\
\hline Ohara et al. [47] & $\begin{array}{l}\text { To support the function of collagen peptides in } \\
\text { stimulating dermal fibroblasts proliferation and } \\
\text { synthesis of hyaluronic acid. }\end{array}$ & $\begin{array}{l}\text { In this study eight different collagen derived peptides, containing Hyp, } \\
\text { were analysed. Positive effect on the proliferation was observed for } \\
\text { Ala-Hyp, Ala-Hyp-Gly and Pro-Hyp. Pro-Hyp induced the maximal } \\
\text { stimulation of cell proliferation of } \sim 1.5 \text { fold. Further investigation was } \\
\text { performed on the effect of different concentrations of Pro-Hyp. In } \\
\text { addition the same eight peptides were tested to study their effect on } \\
\text { hyaluronic acid synthesis. The results were consistent with the } \\
\text { proliferation study as Pro-Hyp showed highest efficacy, where } 200 \\
\text { nmol/mL induced a } 3.8 \text { fold increase in hyaluronic acid synthesis. In } \\
\text { addition the authors suggest that hyaluronic acid increases hydration of } \\
\text { the extracellular space that aids fibroblast proliferation. }\end{array}$ \\
\hline
\end{tabular}


Table 4. In vivo scientific studies on the efficacy of collagen peptides.

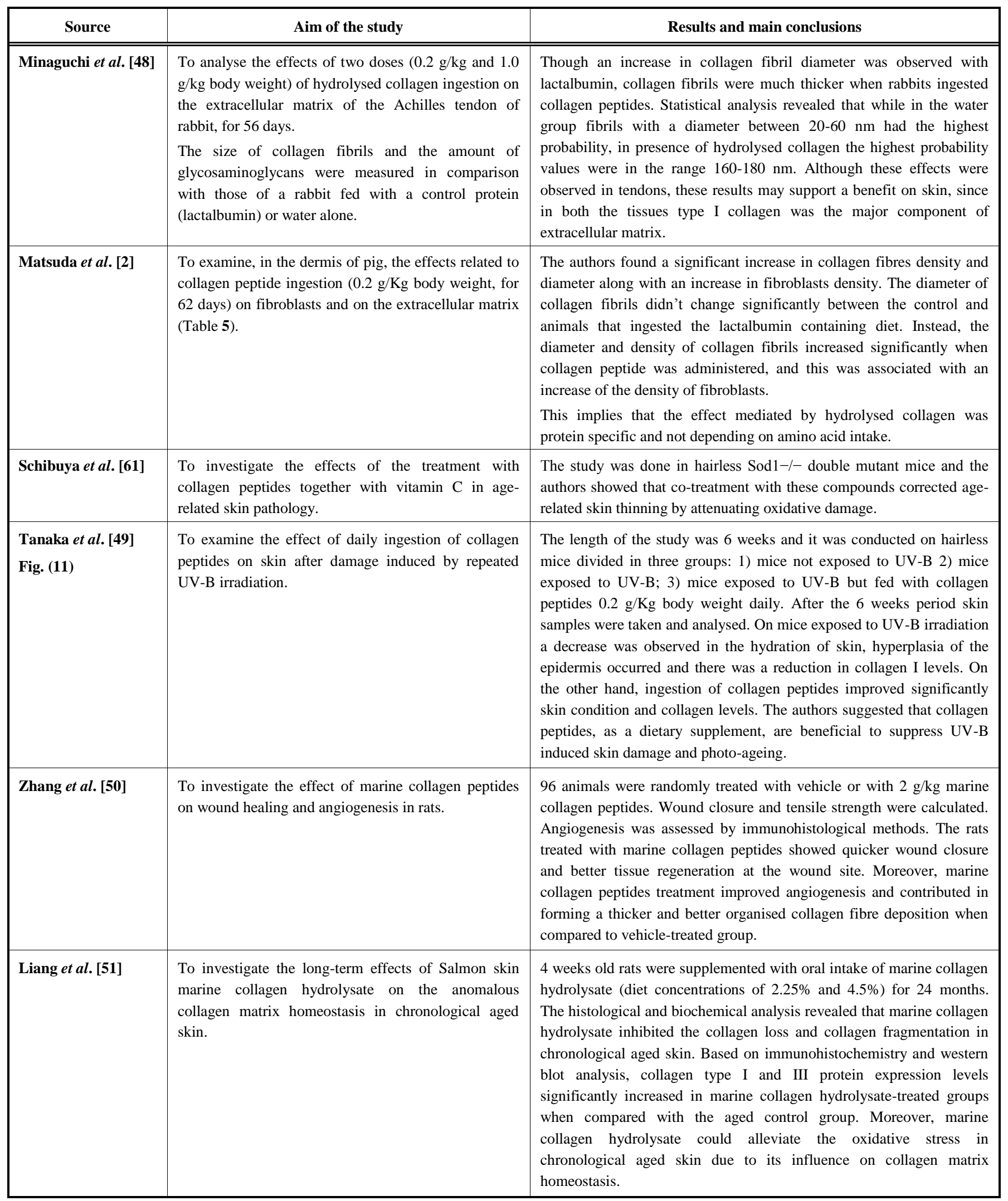


Table 5. Effects of collagen peptides ingestion on fibroblast and extracellular matrix.

\begin{tabular}{|c|c|c|c|}
\hline & a) Control (fibrilser) & b) Lactalbumin & c) Collagen peptide \\
\hline \hline Density of fibroblast (cells/mm2) & $33.3 \pm 0.9$ & $32.3 \pm 0.7$ & $40.2 \pm 0.9$ \\
\hline Diameter of collagen fibrils (nm) & $103.2 \pm 0.4$ & $102.1 \pm 0.5$ & $106.4 \pm 0.5$ \\
\hline Diameter of collagen fibrils (fibrils/m m2) & $77.9 \pm 2.7$ & $74.3 \pm 2.2$ & $90.5 \pm 1.8$ \\
\hline
\end{tabular}

Full data are shown in Ref. [2]

Table 6. Hydrolysed collagen clinical trials.

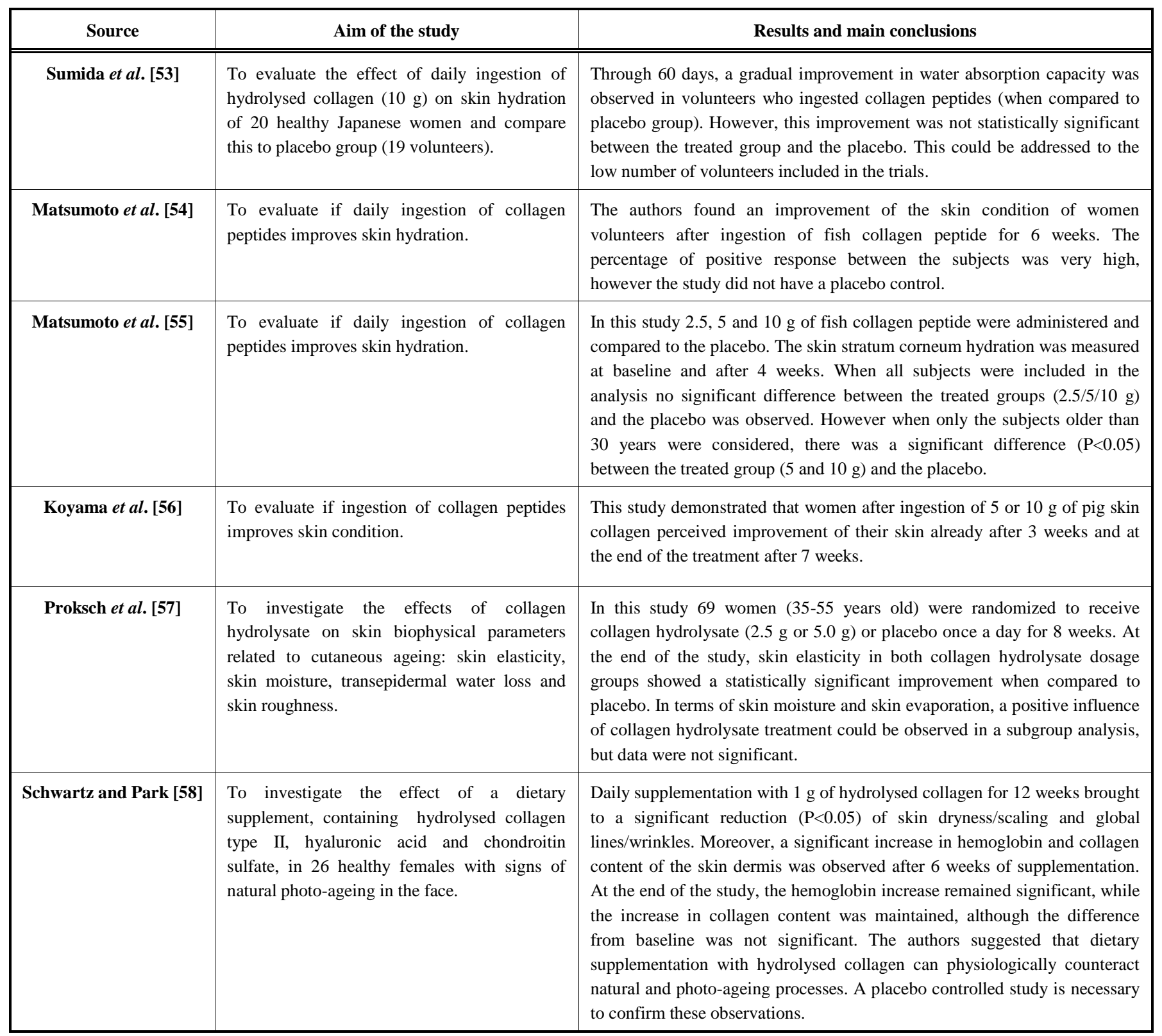


Table 6. Contd.....

\begin{tabular}{|c|c|c|}
\hline Source & Aim of the study & Results and main conclusions \\
\hline Béguin [59] & $\begin{array}{l}\text { To test the efficacy and safety in skin ageing of } \\
\text { a micronutrient supplement, containing marine } \\
\text { collagen proteins, through a } 4 \text { month } \\
\text { randomized double-blind controlled clinical } \\
\text { study. }\end{array}$ & $\begin{array}{l}\text { The trial included } 40 \text { subjects. The supplement was tested against placebo } \\
\text { for a period of } 3 \text { months followed by } 1 \text { month without supplementation to } \\
\text { assess lasting effects. Efficacy measurements were: skin surface evaluation, } \\
\text { ultrasound measurement of sun-exposed skin and protected areas and } \\
\text { photographic assessment. When compared to placebo, all investigated } \\
\text { parameters showed a continuous and significant improvement in the group } \\
\text { taking the supplement during the } 3 \text { months of trial }(\mathrm{P}<0.01) \text {. Photographs } \\
\text { showed visible improvement of the overall skin appearance and a reduction } \\
\text { of fine lines. In the active group, ultrasound measurements showed an } \\
\text { increase in dermis density of up to } 78 \% \text {. The final assessment, after } 1 \text { month } \\
\text { without supplementation, showed no further improvements and there was a } \\
\text { slight decrease in most improved parameters. No treatment-related side } \\
\text { effects were reported. The study demonstrated that the supplement may be } \\
\text { effective to protect the skin and support its repair process. }\end{array}$ \\
\hline
\end{tabular}

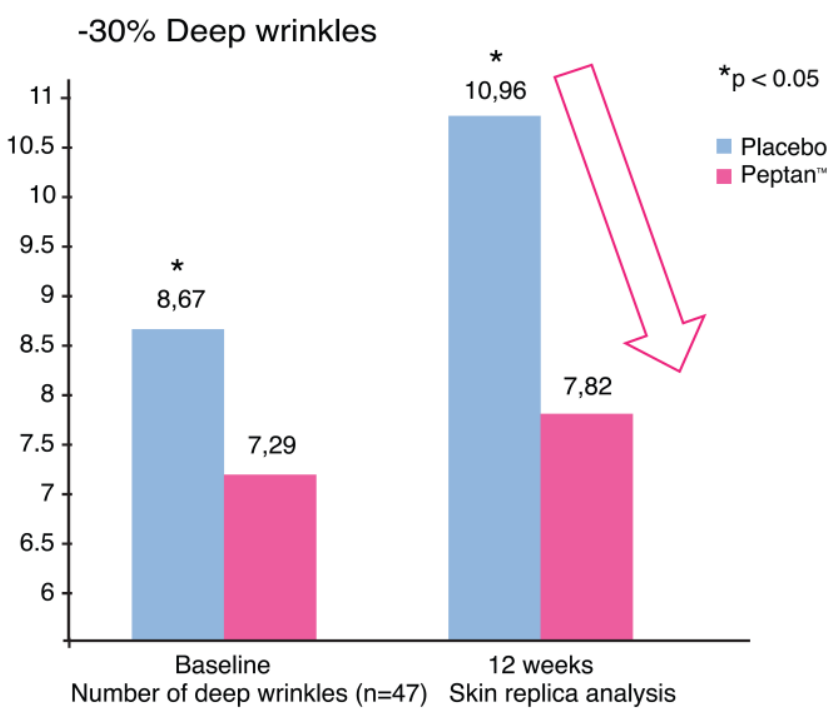

Fig. (13). Clinical trial on reduction of deep wrinkles. (Unpublished results by a study from Rousselot).

\section{THERAPEUTIC IMPLICATIONS}

The evidence supporting the efficacy of hydrolysed collagen in treating the many sequelae of skin ageing (wrinkles, skin thickening etc.) has led to the development of a number of functional foods (food containing additives which provide extra nutritional value) also known as nutraceuticals which contain hydrolysed collagen. Various studies are ongoing to prove the clinical efficacy and safety of these promising new products.

\section{CONCLUSION}

The skin is the largest organ of the human body and represents the main barrier to the external environment. Collagen, elastin and hyaluronic acid are the skin main components and have an important role in maintaining its structure and hydration.

The collagen family consists of 28 different proteins, which account for $25 \%-35 \%$ of the total protein mass in mammals. Type I collagen is the most abundant in human skin $(80 \%)$ with type III collagen making up the remainder of skin collagen $(15 \%)$. The collagen in the skin is mainly produced by fibroblasts.

Hydrolysed collagen consists of small peptides with low molecular weight, enriched in specific amino acids: glycine, proline and hydroxyproline. Due to its low molecular weight, hydrolysed collagen is highly digestible, absorbed and distributed in the different tissues of the human body. Several experiments have shown that collagen peptides can be efficiently absorbed and distributed to the dermis, the deepest layer of the skin, where they can stimulate the proliferation and motility of fibroblasts; induce an increase in the density and diameter of collagen fibres; increase hyaluronic acid production and activate protection against UVA radiation. 
To date several controlled clinical trials have been performed proving the efficacy and benefits of collagen peptides on skin properties, such as hydration, elasticity and reduction of wrinkles and recently a number of therapeutic formulations of hydrolysed collagen have been developed for the treatment of skin ageing. These fall into the category of nutraceuticals - products offering real benefits to all those with ageing skin.

\section{CONFLICT OF INTEREST}

The authors confirm that this article content has no conflicts of interest.

\section{AKNOWLEDGEMENTS}

Declared none.

\section{REFERENCES}

[1] Heino J. The collagen family members as cell adhesion proteins. Bioessays 2007; 29(10): 1001-10.

[2] Matsuda N, Koyama Y, Hosaka Y, et al. Effects of ingestion of collagen peptide on collagen fibrils and glycosaminoglycans in the dermis. J Nutr Sci Vitaminol (Tokyo) 2006; 52(3): 211-5.

[3] Myllyharju J, Kivirikko KI. Collagens and collagen-related diseases. Ann Med 2001; 33(1): 7-21.

[4] Ricard-Blum S. The collagen family. Cold Spring Harb Perspect Biol 2011; 3(1): a004978.

[5] Gelse K, Poschl E, Aigner T. Collagens--structure, function, and biosynthesis. Adv Drug Deliv Rev 2003; 55(12): 1531-46.

[6] Birk DE, Fitch JM, Babiarz JP, Linsenmayer TF. Collagen type I and type $\mathrm{V}$ are present in the same fibril in the avian corneal stroma. J Cell Biol 1988; 106(3): 999-1008.

[7] Mayne R. Cartilage collagens. What is their function, and are they involved in articular disease? Arthritis Rheum 1989; 32(3): 241-6.

[8] Lodish H, Berk A, Zipursky SL, et al. Molecular Cell Biology $4^{\text {th }}$ edition. New York: W. H. Freeman; 2000. Section 22.3, Collagen: The fibrous proteins of the matrix. Internet: http://www.ncbi.nlm.nih.gov/books/NBK21582/

[9] Fleischmajer R, MacDonald ED, Perlish JS, Burgeson RE, Fisher LW. Dermal collagen fibrils are hybrids of type I and type III collagen molecules. J Struct Biol 1990; 105(1-3): 162-9.

[10] Krieg T, Aumailley M. The extracellular matrix of the dermis: flexible structures with dynamic functions. Exp Dermatol 2011; 20(8): 689-95.

[11] Narayanan AS, Page RC, Swanson J. Collagen synthesis by human fibroblasts. Regulation by transforming growth factor-beta in the presence of other inflammatory mediators. Biochem J 1989; 260(2): 463-9.

[12] Kligman LH. Photoaging. Manifestations, prevention, and treatment. Dermatol Clin 1986; 4(3): 517-28.

[13] Guercio-Hauer C, Macfarlane DF, Deleo VA. Photodamage, photoaging and photoprotection of the skin. Am Fam Physician 1994; 50(2): 327-32.

[14] Naylor EC, Watson RE, Sherratt MJ. Molecular aspects of skin ageing. Maturitas 2011; 69(3): 249-56.

[15] Baumann L. Skin ageing and its treatment. J Pathol 2007; 211(2): 241-51.

[16] Prottey C. Essential fatty acids and the skin. Br J Dermatol 1976; 94(5): 579-85.

[17] Dykes PJ, Marks R, Davies MG, Reynolds DJ. Epidermal metabolism in heredopathia atactica polyneuritiformis (Refsum's disease). J Invest Dermatol 1978; 70(3): 126-9.

[18] De Spirt S, Stahl W, Tronnier H, et al. Intervention with flaxseed and borage oil supplements modulates skin condition in women. $\mathrm{Br}$ J Nutr 2009; 101(3): 440-5.

[19] Oikarinen A. The aging of skin: chronoaging versus photoaging. Photodermatol Photoimmunol Photomed 1990; 7(1): 3-4.

[20] Uitto J. Understanding premature skin aging. N Engl J Med 1997; 337(20): 1463-5.
[21] Andrea F. La scienza della bellezza: le basi biochimiche e formulative in medicina estetica. Officina Editoriale Oltrarno S.r.l. Firenze 2012.

[22] Tanaka H, Ono Y, Nakata S, Shintani Y, Sakakibara N, Morita A. Tobacco smoke extract induces premature skin aging in mouse. J Dermatol Sci 2007; 46(1): 69-71.

[23] Varani J, Dame MK, Rittie L, et al. Decreased collagen production in chronologically aged skin: roles of age-dependent alteration in fibroblast function and defective mechanical stimulation. Am J Pathol 2006; 168(6): 1861-8.

[24] El-Domyati M, Attia S, Saleh $\mathrm{F}$, et al. Intrinsic aging $v s$ photoaging: a comparative histopathological, immunohistochemical, and ultrastructural study of skin. Exp Dermatol 2002; 11(5): 398405.

[25] Fisher GJ, Wang ZQ, Datta SC, Varani J, Kang S, Voorhees JJ. Pathophysiology of premature skin aging induced by ultraviolet light. N Engl J Med 1997; 337(20):1419-28.

[26] Yin L, Morita A, Tsuji T. Alterations of extracellular matrix induced by tobacco smoke extract. Arch Dermatol Res 2000; 292(4):188-94.

[27] Dhabhar FS, McEwen BS. Acute stress enhances while chronic stress suppresses cell-mediated immunity in vivo: a potential role for leukocyte trafficking. Brain Behav Immun 1997; 11(4): 286306.

[28] Sephton SE, Sapolsky RM, Kraemer HC, Spiegel D. Diurnal cortisol rhythm as a predictor of breast cancer survival. J Natl Cancer Inst 2000; 92(12): 994-1000.

[29] Stahn C, Buttgereit F. Genomic and nongenomic effects of glucocorticoids. Nat Clin Pract Rheumatol 2008; 4(10): 525-33.

[30] Boscaro M, Barzon L, Fallo F, Sonino N. Cushing's syndrome. Lancet 2001; 357(9258): 783-91.

[31] Roupe G. Skin of the aging human being. Lakartidningen 2001; 98(10): 1091-5.

[32] Watanabe-Kamiyama M, Shimizu M, Kamiyama S, et al. Absorption and effectiveness of orally administered low molecular weight collagen hydrolysate in rats. J Agric Food Chem 2010; 58(2): 835-41.

[33] Richelle M, Sabatier M, Steiling H, Williamson G. Skin bioavailability of dietary vitamin E, carotenoids, polyphenols, vitamin C, zinc and selenium. Br J Nutr 2006; 96(2): 227-38.

[34] Oesser S, Adam M, Babel W, Seifert J. Oral administration of (14)C labeled gelatin hydrolysate leads to an accumulation of radioactivity in cartilage of mice (C57/BL). J Nutr 1999; 129(10): 1891-5.

[35] Iwai K, Hasegawa T, Taguchi Y, et al. Identification of foodderived collagen peptides in human blood after oral ingestion of gelatin hydrolysates. J Agric Food Chem 2005; 53(16): 6531-6.

[36] Ohara H, Matsumoto H, Ito K, Iwai K, Sato K. Comparison of quantity and structures of hydroxyproline-containing peptides in human blood after oral ingestion of gelatin hydrolysates from different sources. J Agric Food Chem 2007; 55(4): 1532-5.

[37] Boullin DJ, Crampton RF, Heading CE, Pelling D. Intestinal absorption of dipeptides containing glycine, phenylalanine, proline, beta-alanine or histidine in the rat. Clin Sci Mol Med 1973; 45(6): 49-58.

[38] Matthews DM, Laster L. Absorption of protein digestion products: a review. Gut 1965; 6(5): 411-26.

[39] Daniel H. Molecular and integrative physiology of intestinal peptide transport. Annu Rev Physiol 2004; 66: 361-84.

[40] Sai Y, Kajita M, Tamai I, Wakama J, Wakamiya T, Tsuji A. Adsorptive-mediated endocytosis of a basic peptide in enterocytelike Caco-2 cells. Am J Physiol 1998; 275(3 Pt 1): 514-20.

[41] Adson A, Raub TJ, Burton PS, et al. Quantitative approaches to delineate paracellular diffusion in cultured epithelial cell monolayers. J Pharm Sci 1994; 83(11): 1529-36.

[42] Christensen N. Role of amino acid transport and contertransport in nutrient and metabolism. Physiologie 1990; 70: 43-77.

[43] Aito-Inoue M, Lackeyram D, Fan MZ, Sato K, Mine Y. Transport of a tripeptide, Gly-Pro-Hyp, across the porcine intestinal brushborder membrane. J Pept Sci 2007; 13(7): 468-74.

[44] Postlethwaite AE, Seyer JM, Kang AH. Chemotactic attraction of human fibroblasts to type I, II, and III collagens and collagenderived peptides. Proc Natl Acad Sci USA 1978; 75(2): 871-5.

[45] Shigemura Y, Iwai K, Morimatsu F, et al. Effect of Prolylhydroxyproline (Pro-Hyp), a food-derived collagen peptide in 
human blood, on growth of fibroblasts from mouse skin. J Agric Food Chem 2009; 57(2): 444-9.

[46] Chen RH, Hsu CN, Chung MY, Tsai WL, Liu CH. Effect of different concentrations of collagen, ceramides, n-acetyl glucosamine, or their mixture on enhancing the proliferation of keratinocytes, fibroblasts and the secretion of collagen and/or the expression of mRNA of type i collagen. J Food Drug Anal 2008; 16(1): 66-74.

[47] Ohara H, Ichikawa S, Matsumoto $\mathrm{H}$, et al. Collagen-derived dipeptide, proline-hydroxyproline, stimulates cell proliferation and hyaluronic acid synthesis in cultured human dermal fibroblasts. J Dermatol 2010; 37(4): 330-8.

[48] Minaguchi J, Koyama Y, Meguri N, et al. Effects of ingestion of collagen peptide on collagen fibrils and glycosaminoglycans in Achilles tendon. J Nutr Sci Vitaminol 2005; 51(3): 169-74.

[49] Tanaka M, Koyama Y, Nomura Y. Effects of collagen peptide ingestion on UV-B-induced skin damage. Biosci Biotechnol Biochem 2009; 73(4): 930-2.

[50] Zhang Z, Wang J, Ding Y, Dai X, Li Y. Oral administration of marine collagen peptides from Chum Salmon skin enhances cutaneous wound healing and angiogenesis in rats. J Sci Food Agric 2011; 91(12): 2173-9.

[51] Liang J, Pei X, Zhang Z, Wang N, Wang J, Li Y. The protective effects of long-term oral administration of marine collagen hydrolysate from chum salmon on collagen matrix homeostasis in the chronological aged skin of Sprague-Dawley male rats. J Food Sci 2010; 75(8): 230-8.

[52] Puizina-Ivic N. Skin aging. Acta dermatovenerologica Alpina, Panonica, et Adriatica 2008; 17(2): 47-54.
[53] Sumida E, Hirota A, Kuwaba K. The effect of oral ingestion of collagen peptide on skin hydration and biochemical data of blood. J Nutr Food 2004; 7 : 45-52.

[54] Matsumoto H, Ohara H, Ito K, Nakamura Y, Takahashi S. Clinical effect of fish type I collagen hydrolysate on skin properties. ITE Lett 2006; (7): 386-90.

[55] Ohara $\mathrm{H}$, Ito $\mathrm{K}$, Iida $\mathrm{H}$, Matsumoto $\mathrm{H}$. Improvement in the moisture content of the stratum corneum following 4 weeks of collagen hydrolysate ingestion. Nippon Shokuhin Kogaku Kaishi 2009; 56: 137-45.

[56] Koyama Y. Effect of collagen peptide on the skin. Shokuhinto Kaihatsu 2009; 44: 10-2.

[57] Proksch E, Segger D, Degwert J, Schunck M, Zague V, Oesser S. Oral supplementation of specific collagen peptides has beneficial effects on human skin physiology: a double-blind, placebocontrolled study. Skin Pharmacol Physiol 2014; 27(1): 47-55.

[58] Schwartz SR, Park J. Ingestion of BioCell Collagen((R)), a novel hydrolyzed chicken sternal cartilage extract; enhanced blood microcirculation and reduced facial aging signs. Clin Interv Aging 2012; 7: 267-73.

[59] Beguin A. A novel micronutrient supplement in skin aging: a randomized placebo-controlled double-blind study. J Cosmet Dermatol 2005; 4(4): 277-84.

[60] Choi SY, Ko EJ, Lee YH, et al. Effects of collagen tripeptide supplement on skin properties: A prospective, randomized, controlled study. J Cosmet Laser Ther 2014; 16(3): 132-7.

[61] Shibuya S, Ozawa Y, Toda T, et al. Collagen peptide and vitamin $\mathrm{C}$ additively attenuate age-related skin atrophy in Sodl-deficient mice. Biosci Biotech Biochem 2014; 78: 1212-20.

(C) Sibilla et al.; Licensee Bentham Open.

This is an open access article licensed under the terms of the Creative Commons Attribution Non-Commercial License (http://creativecommons.org/licenses/by-nc/3.0/) which permits unrestricted, non-commercial use, distribution and reproduction in any medium, provided the work is properly cited. 